\title{
COMPARISON OF SOME CLINICAL PARAMETERS OF BLOOD OF PERSONS WITH VARYING DEGREES OF ACQUIRED MYOPIA
}

\section{Kolesnyk Yuliia ${ }^{1}$}

DOI: https://doi.org/10.30525/978-9934-571-89-3_79

The research has established that under the myopia, which is considered the most common abnormality of refraction on the planet [1], there are changes in many somatic and functional systems of the human body, in the circulatory system in particular [2-4]. It is known that changes in blood composition are a sensitive marker that reflects the effects of various exogenous and endogenous factors. Therefore, fluctuations in the total number of cell fractions or the shift in the ratio of formed elements can characterize the adaptive-compensatory reserves, the human immune status and reflect the state of its health in general [5-6].

Purpose: to investigate the differences in some indicators of blood count in people with a different (low, medium, high) degree of acquired form of myopia.

In the study after obtaining Informed consent were included 90 volunteers aged 18-35 years, divided according to the degree of development of myopia in 3 groups: 1 - people with the low degree of myopia (up to -3 diopters), 2 - people with the moderate degree of myopia ( -3 to -6 diopters), and 3 - people with the high degree of myopia (from -6 diopters). The diagnosis "acquired myopia" and its degree of manifestation was established of the basis of a doctor's conclusion after the annual medical examination.

${ }^{1}$ Sumy State Pedagogical University named after A.S. Makarenko, Ukraine 
Quantitative hemogram values were investigated on a hemoneal analyzer. The leukogram was counted by the methods of light microscopy in the smears of peripheral blood stained by the Romanovsky-Giemsa [7]. The blood parameters, which were studied: the total amount of leukocytes, erythrocytes, platelets, hemoglobin, hematocrit, thrombocyte, erythrocyte (mean corpuscular volume, mean corpuscular hemoglobin, mean corpuscular hemoglobin concentration, RBC distribution width, RDW CV) and platelets indexes (average platelet count, coefficient large platelets, relative width of platelet distribution).

Blood sampling was performed in the morning before eating with the observance of the medical and bioethical norms [8]. Obtained digital data were processed mathematically by using standard software packages (Microsoft Office Excel 2010, Statistica 6,0).

Results and discussion. All volunteers were analyzed for samples of peripheral blood in order to identify the features of general-clinical indicators, depending on the degree of development of acquired myopia. The comparison was conducted from the level of the average group indicator, established for persons with low myopia.

According to the results, the absolute amount in peripheral blood white blood cells (WBC) among people with moderate myopia is higher by $9.5 \%$, and among people with high myopia - less by $2.3 \%$ (compared with a weak degree of myopia).

In the group of persons with moderate degree of myopia, there were no statistically significant differences in the number of red blood cells (RBC), RBC distribution width (RDW), mean corpuscular volume of erythrocytes (average RBC size, or $\mathrm{MCV}$ ), in terms of relative redistribution volume (RDW CV) a tendency to increase values (by $1.8 \%$ ) was noted. Under the high degree of myopia, all of the above indicators are characterized by lower values (by $3.6 \%, 2.2 \%, 3.2 \%, 3.4 \%$, respectively).

Hematocrit (HCT) in the group of persons with moderate degree of myopia was higher (by $1.8 \%$ ), in the group of people with a high degree - lower by $6.6 \%$ (in comparison with the data of persons with low myopia).

The hemoglobin content (HGB) in the blood of persons with moderate degree of myopia was slightly higher (by $1.5 \%$ ), than in the group of volunteers with low myopia, and with a high degree, on the contrary, the lower (by $4.8 \%$ ). Among persons with moderate myopia, the average hemoglobin amount in the erythrocyte (mean corpuscular hemoglobin, or $\mathrm{MCH}$ ) was not statistically different from that of patients with low myopia, and the mean concentration of hemoglobin in erythrocyte (MCHC) was lower (by $1.8 \%$ ). In the case of high myopia, the opposite trend was noted: the MCHC score did not differ from the mean-group values of persons with low myopia and $\mathrm{MCH}$ was lower by $1.8 \%$.

It should be noted that all of the studied platelet indexes in subjects with moderate degree of myopia were lower than the comparison group (the low degree of myopia): the total platelet count (PLT) - by $6 \%$, the average volume of platelets (MPV) - by $2.7 \%$, the large platelet count (P-LCR) - by $9.8 \%$, the relative platelet distribution width (P-RDW) - by $2.8 \%$. Under the high degree of myopia, we found an increase 
PLT by $2.5 \%$, a decrease MPV by $4.5 \%$ and P-LCR by $12.7 \%$, a slight increase RDW by $1.2 \%$.

The value of platelet crit (PCT) in people with moderate myopia was less (by $9.3 \%$ ) to a greater extent than in people with high myopia (by $3 \%$ ) (compared to the low degree of myopia).

Thus, as a result of the our study, it was found that although the parameters studied were within the age range, but differences in clinical parameters of blood in patients with varying degrees of acquired myopia were revealed. The data obtained are of scientific interest and require for further research.

\section{References:}

1. Morgan, I. G., \& French, A. N., Ashby, R. S., Guo, X., Ding, X., He, M., Rose, K. A. (2018). The epidemics of myopia: aetiology and prevention. Progress in Retinal and Eye Research, 62, 134-149. DOI: 10.1016/j.preteyeres.2017.09.004.

2. Ivanova, N. V., \& Kondratjuk, G. I. (2013). Priobretennaja miopija: integracija faktorov riska razvitija i progressirovanija [Acquired myopia: integration of risk factors of development and progression]. Tavricheskij mediko-biologicheskij vestnik, 16 (3), 171-176.

3. Kolesnyk, Yu. I. (2019). Ocinka stanu klitynnogo imunitetu u osib iz serednim ta vy`sokym stupenem korotkozorosti [Assessment of cellular immunity in people with medium and high degree of myopia]. Bulletin of problems biology and medicine, 1(1), 383-386. DOI: 10.29254/2077-42142019-1-1-148-383-386.

4. Sheiko, V. I., \& Makarenko, M. V., Ivaniura, I. O. (2005). Stan nejrodynamiky ta imunnoyi systemy osib iz korotkozoristyu [State of the neurodynamic and immune system in people with myopia]. Fiziol Zh., 4(51), 55-60.

5. Haitov, R. M., \& Ignat'eva, G. A. Sidorovich, I. G. (2010). Immunologija. Norma i patologija [Immunology: norm and pathology]. M.: Medicina.

6. Jarilin, A. A. (2010). Immunologija [Immunology]. M.: GJeO-TAR-Media.

7. Men'shikov, V. V. (1987). Laboratornyye metody issledovaniya v klinike [Laboratory research methods in the clinic]. M.: Meditsina.

8. Dodatkovyy protokol do konventsiyi pro prava lyudyny ta biomedytsynu $\mathrm{v}$ haluzi biomedychnykh doslidzhen' (ETS N 195) (2005). [Additional Protocol to the Convention on Human Rights and Biomedicine in the Field of Biomedical Research]. Verkhovna Rada Ukrayiny. Retrieved from: http://zakon2.rada.gov.ua/laws/show/994_686/. 